\title{
Global Value Chains and Economic Development: What Impact on The Moroccan Economy?
}

\author{
Bilal Lotfi ${ }^{1, *}$ and Ismail Lotfi ${ }^{2,3}$ \\ ${ }^{1}$ Laboratory of Engineering Sciences, National School of Applied Sciences, Ibn Tofail University, Kenitra, Morocco. \\ ${ }^{2}$ Laboratoire de Recherche et d'Etudes en Management, Entrepreneuriat et Finance (LAREMEF), ENCGF, \\ Sidi Mohamed Ben Abdellah University, Fez, Morocco. \\ ${ }^{3}$ Laboratoire Systèmes et Environnements Durables (LSED), Faculté des Sciences de l'Ingénieur (FSI), \\ Université Privée de Fès (UPF), Fez, Morocco.
}

\begin{abstract}
Globalization has changed the way goods and services are produced. The activities that form the value chains of many products and services are increasingly fragmented across the globe and between firms. But the question is how we get positive economic and social benefits by taking part in these global value chains. In the case of Morocco, it appears that the current form of its integration in Global Value Chains (GVCs) has only a limited effect on economic growth in the long-term. Indeed, despite the continued growth of Moroccan exports since 2011, the local added value in these exports has not increased so much. Consequently, the current stage of Morocco in GVCs does not allow improvement of per capita income and employment rates. In this respect, moving upmarket in GVCs and discovering of a new, more complex sector is no minor detail, but proves to be an absolute necessity for the territorial development of Morocco.
\end{abstract}

Keywords: Global Value Chains, Economic development, Exports, VECM.

\section{INTRODUCTION}

With the fast development of international trade, only countries that were able to integrate the world market have been able to find a model of strong, rapid and sustainable growth. The first step in this development process is to stop resorting to the old trade policies characterized in most developing countries by substituting imports with domestic products in order to reduce foreign dependency and stimulate economic growth. Contrarily, several recent studies have shown that trade policies limited to promoting exports andrestrain imports are no longer enough to answer the key questions of economic development and international competitiveness (OECD, 2014).It is for this reason that several developing countries use their participation in GVCs as a mean of economic growth, improving employment and reducing poverty (OECD and WTO, 2014). Theyalso benefit from a structural transformation of their productive structure by reallocating resources to new and more productive activities(Jaidi and Msadfa, 2017).

Today, the production process can be split between several countries through geographic reorganization and separation of production stages. This geographic fragmentation of the global production process is called the «Global Value Chain »(GVC). Nowadays, intermediate goods have become the

*Address correspondence to this author at Laboratory of Engineering Sciences, National School of Applied Sciences, Ibn Tofail University, Kenitra, Morocco; E-mail: bil.lotfi@gmail.com main engine of growth in international trade. In 2012, they represented around $65 \%$ of world imports(African Development Bank and al., 2014). Based on this observation, imports are no longer consideredas a sign of "economic weakness" but rather an essential component of exports, especially in complex value chains(OECD, 2014). Thus, openness to international trade and investment is a must, but not a sufficient condition to take full advantage of global value chains, and to move upmarket in these value chains(OECD, 2014).

In the case of Morocco, despite the efforts made to liberalize foreign trade, multiply the number of trade agreements and make greater contribution in global value chains, the country contributes marginally to world trade measured by value added (Jaidi and Msadfa, 2017). In this context, the country's export profile has become problematic(African Development Bank and al., 2014). This is due to limited integration of Morocco at some stagein manufacturing activities in GVCs, usually assembly. Consequently, the industry's contribution to wealth creation has remained so limitedand even the contribution of this sector to national value added has decreased from $17.6 \%$ in 1999 to $14.5 \%$ in 2012(Jaidi and Msadfa, 2017).

Thus, the Moroccan development model is still not very inclusive and does not take sufficient advantage of the opportunities offered by international trade. Therefore, the main point of this work is to understand the global value chains' functioning, their impact on Morocco's economic performance and scope for public action to be taken to benefit from it. 


\section{LITERATURE REVIEW}

\subsection{Definition and Concept}

The term value chain, created by Michael Porter in his book "Competitive advantage", comes from the theories of management and business organizations. It covers the different production activities of a good or a service within a company. This concept is therefore part of a systematic approach that aims at analyzing the specific activities by which companies can create value, and generate a competitive advantage in order to identify the steps that contribute most significantly to their profit margin (Brulhart and al., 2015).

With the development of international trade and the internationalization of firms, a country's trade is no longer restricted to the national level only, but is replaced by a fragmentation of the production process over several countries. We call these networks the Global Value Chains (GVCs). Thus, this notion of value chain refers to important themes which are globalization and international division of labor (IDT). Various tasks along the production chain can be fragmented between companies across the globe, depending on the respective comparative advantages of different countries (African Development Bank and al., 2014). This implies that a country's participation in GVCs is dictated by economic fundamentals, but public policies are important to increase this participation and broaden their corresponding benefits(World Bank, 2019).

Therefore, the traditional measure of international trade may no longer be sufficient. Several works are trying to remove the effect of double counting induced by global value chains, by measuring international trade in terms of added value rather than gross trade flows. This method will allow us to determine the added value flows created by countries during the production of exported goods and services. For example, in terms of gross exports, the German exports exceeded the USA's by almost $40 \%$ in 2009 , but by only $10 \%$ in terms of added value(OECD, 2014). This concept has been simplified by describing the pattern of trade between three countries A, $\mathrm{B}$ and $\mathrm{C}$, where country A exports goods entirely produced on its territory for $\$ 100$, to country B which perfects them, before exporting them to country $\mathrm{C}$ where they will be consumed. B adds $\$ 10$ in value to these goods and therefore exports $\$ 110$ to $\mathrm{C}$. According to traditional indicators, the total commercial value of all exports and imports is $\$ 210$, while only $\$ 110$ of added value was generated during the production of these goods. Consequently, the measurement of trade in added value also modifies bilateral trade balances. For instance, China's trade surplus with the United States in 2009 decreases by 60 billion USD (one third), when calculated using added value(OECD, 2014).

\subsection{GVC Integration Forms}

Integration into a global value chain means that a country becomes part of an international production network in which intermediate goods come from many different places, and are assembled in a third country(African Development Bank and al., 2014). Measuring foreign trade in terms of value added indicates the countries level of integration upstream or downstream at the GVC.
Upstream integration represents the share of foreign added value in a country's exports. "This consists in studying the importance of foreign factors in local production" (De Baker and Miroudot, 2013; López González and Holmes, 2011; OCDE, 2013)1. While downstream integration represents the share of a country's added value exports incorporated in the exports of other countries. The figure below illustrates the upstream and downstream integration.

Fig. (1). Illustration of upstream and downstream integration.

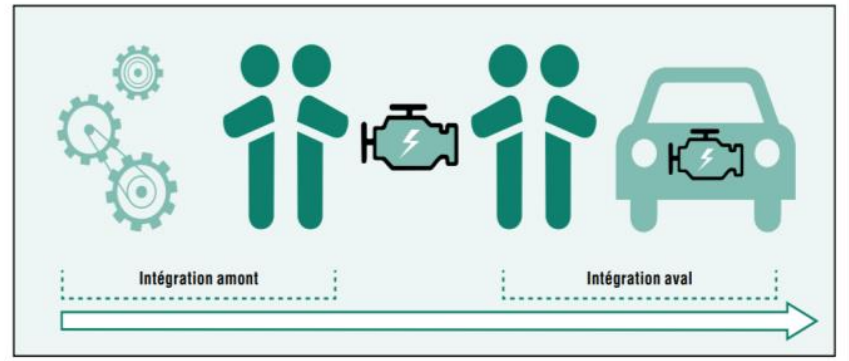

Source: Africa, Development Bank and al., 2014

A country's position in a global value chain can define expected return from that chain. Hence, "Activities such as research and development or design, along with certain services, create more added value than assembly"(OECD, 2013).

\subsection{GVC and the Economic Development}

International trade expanded rapidly after 1990 thanks to the expansion of global value chains (GVCs). "The emergence of these new production models has made counterproductive, the trade policies that encourage exports and restrict imports"(OECD, 2014). Thus, global value chains are transforming world trade, since imports are no longer seen as a "sign of weakness".

Nowadays, traditional foreign trade is nolonger considered as an engine of economic development or even an indicator of the rigidity of the production structure. Since the 2008 global financial crisis, and the coronavirus pandemic, trade growth has been sluggish and the expansion of GVCs has slowed. Similarly, trade conflicts between large countries could lead to a contraction in trade or a segmentation of GVCs(World Bank, 2019).

In this context, economies that aim to integrate GVCs must analyze the positive or negative spillovers from such a policy to determine how to benefit from it in terms of growth, employment and income. For these reasons, GVCs must be more inclusive in order to confer increased benefits to developing countries (WTO)2. The cases of China, Costa Rica, Mexico, the Czech Republic, and Thailand show that countries' participation in GVCs can accelerate development and industrialization(OECD, 2014).

\footnotetext{
${ }^{1}$ Cited by African Development Bank, OECD, UNDP, 2014. Perspectives économiques en Afrique 2014: Les chaînes de valeur mondiales et l'industrialisation de l'Afrique, Perspectives économiques en Afrique. ${ }^{2} \mathrm{https} / / /$ cutt.ly/5yVchoo. Accessed May 20, 2020.
} 


\subsubsection{GVC and Economic Growth}

The emergence of value chains has far-reaching implications for developing countries' policies on economic growth. Thereby, integration into a GVC, which is generally associated with openness to new production networks, large world markets, foreign capital, know-how and technologies, is often the first step to move along a sustainable development path. In addition, developing economies can open their markets to Foreign direct investment and strengthen local firms' capacity to intervene in international trade(OECD, 2014). Thus, the GVC participation is important for economic development, even the ability of countries to prosper depends on the level of their integration into these production networks(Gereffi and Lee, 2012).

From an economic point of view, « The correlation between GVC participation and growth in local added value in exports was stronger in the 2000s than in the 1990s; this suggests that global value chains are gaining importance in world trade »(African Development Bank and al., 2014). Similarly, the works of Hummels, Ishii and Yi (2001), show that global value chains are largely behind most of the world trade growth between 1970 and 1990. The works of Baldwin and Lopez-Gonzales (2013), show that this growth accelerated further in 1995-2009. Montalbano and al. (2018) confirm the positive relationship between participation in international activities and business performance, emphasizing that the position in global value chains is also important. Thus, growth is generally higher when countries move from the export of basic products to the export of simple manufactured products (clothing, for example) like Bangladesh, Cambodia and Viet Nam(World Bank, 2019). In fact, through their participation in a value chain, countries and companies can acquire new capacities that allow them to move upmarket, and increase their added value share in global value chain.

A study by Raei and al. (2019) shows that participation in global value chains are positively correlated to per capita income (see Fig. 2). But despite this, these correlations do not identify how participation in global value chains can have an impact on countries' per capita income. However, Kummritz (2016) shows that an increase in global value chains participation leads to an increase in domestic added value, but the effect is only significant for middle- and highincome countries.

Yet, most of the created value is captured by companies that own the intellectual assets behind the creation of value: brands, patents, designs and models, and also organizational and distribution networks. Some emerging economies are therefore seeking to intensify investments in these types of assets to increase the created value in GVCs and then develop their own value chains. Consequently, integration into global value chains is not a quick fix for achieving economic development(OECD, 2014). A study by World Economic Forum (2013) reveals that GDP could increase by $4.7 \%$ and exports by $14.5 \%$ if each country improves its border administration as well as its transport and communication infrastructure.

Recent studies show that diversification and exports' sophistication is an essential condition for boosting growth and promoting foreign trade(Lotfi and Karim, 2017, 2016a, 2016b).These studies also show that building a sustainable and inclusive economic model cannot be achieved without progressing towards increasingly sophisticated products. But the transitions between each level of export sophistication is always accompanied with increased demands on skills, connectivity and regulatory institutions(World Bank, 2019). This works in favor of productive structural transformation for developing countries. Nevertheless, it's important to point out that countries with an efficient judiciary system export more, then move easily to more sophisticated sectors(OECD, 2014).

\subsubsection{GVC and Productivity}

The emergence of GVCs challenges some conceptions of globalization economic impacts, but confirms others. One of the main impacts of GVCs is their role in enhancing growth

Fig. (2). GVCs and Economic Development.
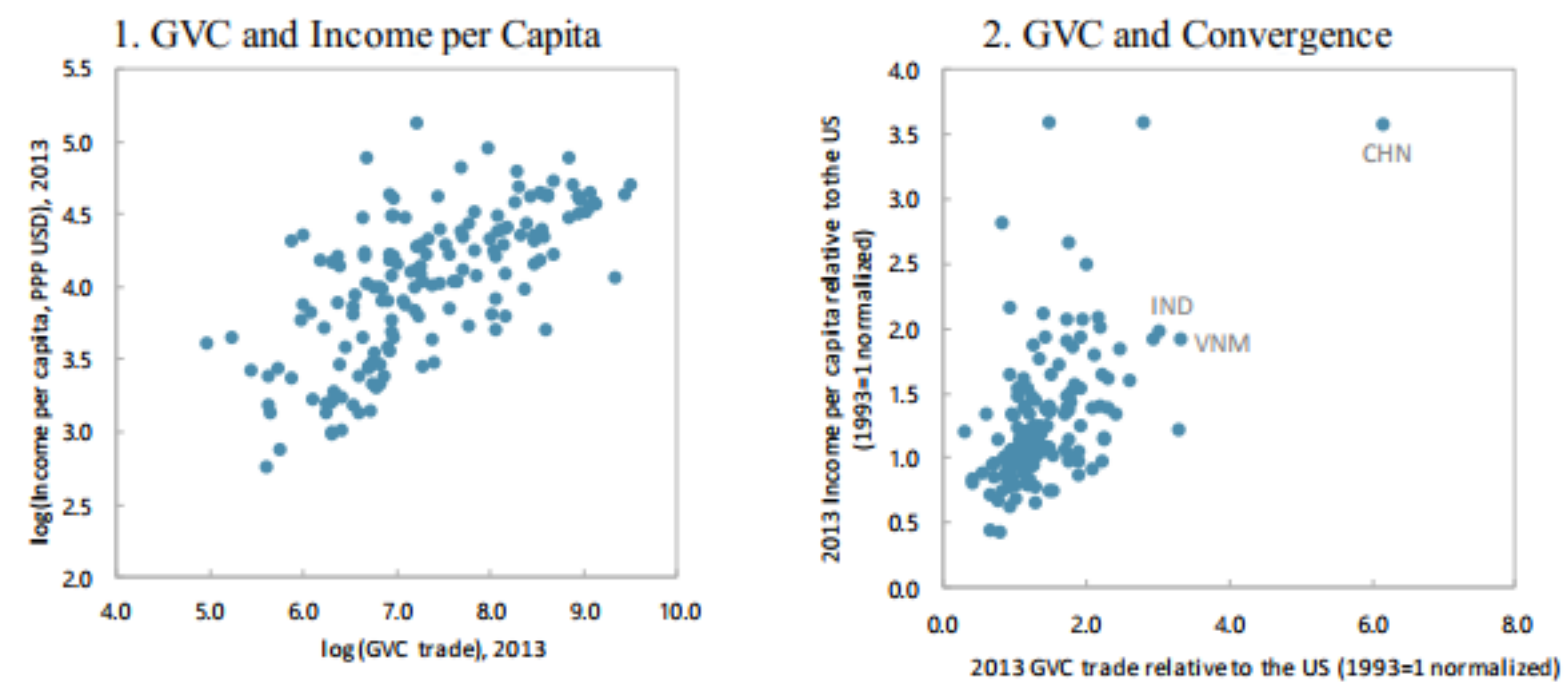

Source: Raei and al. (2019). 
and productivity(OECD, 2014). In Ethiopia, for example, companies participating in GVCs are more than twice as productive as those limited to traditional trade. Likewise, productivity has increased in countries like Bangladesh, China and Viet Nam, which have become more integrated in GVCs (World Bank, 2019). This study shows that generally a $1 \%$ increase of this participation increases the per capita income by more than $1 \%$, while traditional trade increases it by only $0.2 \%$. Accordingly, productivity growth rates at the national and firm levels serve as a standard indicator of economic development.

The globalization effects on productivity are the result of additional efficiencies generated by international competition, reorganizing the activity of a company and economies of scale. In addition, participation in GVCs can improve productivity by making easier to access cheaper or higher quality intermediate inputs (OECD, 2014).

New evidence also reveals how trade liberalization can raise the Productivity level in downstream manufacturing firms (Arnold and al., 2016). Baldwin and Yan (2014) found that the productivity of Canadian companies that integrated GVC increased by more than $5 \%$ compared to other national companies in the first year, and by $9 \%$ four years later. Contrariwise, companies leaving a GVC, lost $1 \%$ of productivity in the first year, and 8\% during 4-year(Augier and al., 2019).

\subsubsection{GVC and Employment}

Economic development and social development must progress in parallel, which means that it must be accompanied by an increase in employment and improved working conditions. According to a study by World Bank (2019), GVCs can improve the quality of jobs, but their relationship to total employment is complex.

As shown above, companies integrated into GVCs are generally more productive, which allows them to mobilize less labor in their manufacturing process. In this context, a series of OECD studies show that « economic globalization has so far had little or no effect on total employment » and «that there is no systematic correlation between the degree to which countries are open to trade and their unemployment rates »(OECD, 2014). Thus, these works conclude that total employment level is determined more by long-term labor force growth, economic variables, and labor market authorities, than by globalization. These same conclusions have been confirmed by the work of African development bank and al. (2014) in the case of African countries. These studies have shown that "African countries find it difficult to advance employment solely by relying on participation in global value chains; to do this they must increase the local added value content of their exports". In other words, employment has only increased in countries where participation in GVCs increased significantly local added value in exports.

However, even if participation in GVCs does not automatically affect total employment, it has effects on its composition. "The offshoring of some production stages within a global value chain usually involves more labor-intensive processes, leading to a decline in corresponding employment. But offshoring also leads to increased productivity and competitiveness in other activities, leading to employment growth that can compensate for job losses caused by offshoring". So, the total level of employment can be maintained but its composition may change, "as newly created jobs often require higher skills than those required for lost jobs"(OECD, 2014). As a result, GVCs are accompanied by structural transformation in developing countries, resulting from a labor transfer from less productive activities to more productive activities in manufacturing and services industries(World Bank, 2019). In addition, several studies show that GVC is associated with better working conditions.

Finally, overvalued exchange rates and restrictive labour regulations increase the labour cost and thus prevent countries from taking advantage of them.

\section{METHODOLOGY}

The main objective of this paper is to assess the impact of the integration of the Moroccan economy into global value chains (GVCs). The interest of such reflection is testing the ability of Moroccan economic and trade policies to generate potential income earnings and take full advantages of its current integration at the GVCs.

To answer these questions, the followed methodology will consist firstly of analyzing - from a macroeconomic point of view - the evolution of Morocco's integration in GVCs since the 1990s. Then, we will try to assess the impact of such a policy on Morocco's economic performance by using econometric methods. This obviously involves assessing the key parameters that contribute the most to economic growth and social development via global value chains in the short and long-term. Finally, we will try to enrich the debate on the capacity of Morocco's trade policy to take advantage of its current position in global value chains in order to list some recommendations.

\subsection{Data}

As mentioned above, measuring trade flows in terms of added value makes it possible to separate the local and foreign added value contents of exports, which mitigates, if not eliminates, the double counting exports issue.

For this purpose, a large amount of data is necessary. The World Trade Organization (WTO) and the Organization for Economic Co-operation and Development (OECD) have developed databases in order to compile this information. The EORA database of the United Nations Conference on Trade and Development ((UNCTADEORA-GVC) uses also the available information to analyze the integration of Morocco into GVCs. In addition, trade data measured in added value (TiVA) account the value that each country adds during the production of goods and services.

As part of this work, we have tried to identify a large number of macroeconomic variables associated with our study, as well as indicators of participation in global value chains. The used data covers the period from 1990 to 2018, i.e. 29 observations. The used variables in this study are:

I. Macroeconomic variables:

- GDP per capita, noted [GDPc] in dollars;

- $\quad$ Balance of payments, noted [BP] as \% of GDP; 
- Unemployment rate, noted [UNEMP] in \% of the population.

II. GVC participation indicators:

- Export of goods and services, noted [EXP] in dollars;

- Domestic Value Added in exports, noted [DVA] in dollars;

- Foreign Value Added in exports, noted [FVA] in dollars;

- The Herfindahl-Hirschman index, noted [HHI], which measures the export concentration;

- Real effective exchange rate, noted [REER].

Variables are expressed in logarithmic form so that their coefficients can be interpreted as elasticities, excepts indices and rates. This specification has the advantage of avoiding heteroscedasticity problems.

\subsection{Modeling}

The most difficult part of estimating a growth model is to identify the appropriate explicative variables, given that classical theory is not sufficient to provide a generalized model to be able to identify them. Vector modeling overcomes this risk by integrating the models with simultaneous equation, which make it possible to consider the notion of lagged variables and permutations between endogenous and exogenous variables. This type of model is very useful for describing the dynamic behavior of the studied variables. It allows as well testing the existence and stability of long-term relationships.

In a similar case, it appears that Vector Error Correction Model (VECM) is the most relevant tool for estimating the impact of the participation of global value chains in economic development in Morocco. Based on the variables mentioned above, the proposed model for this reason is formulated as follows:

$\log (G D P c)_{t}=\alpha\left[\begin{array}{c}1 \\ -\beta_{1} \\ -\beta_{2} \\ -\beta_{3} \\ -\beta_{4} \\ -\beta_{5} \\ -\beta_{6} \\ -\beta_{7}\end{array}\right]\left[\begin{array}{c}\log (G D P c)_{t-1} \\ \log (D V A)_{t-1} \\ \log (F V A)_{t-1} \\ \log (E X P)_{t-1} \\ B P_{t-1} \\ H H I_{t-1} \\ R E E R_{t-1} \\ U N E M P_{t-1}\end{array}\right]+\left[\begin{array}{l}\gamma_{1} \\ \gamma_{2} \\ \gamma_{3} \\ \gamma_{4} \\ \gamma_{5} \\ \gamma_{6} \\ \gamma_{7} \\ \gamma_{8}\end{array}\right]\left[\begin{array}{c}\Delta \log (G D P c)_{t-1} \\ \Delta \log (D V A)_{t-1} \\ \Delta \log (F V A)_{t-1} \\ \Delta \log (E X P)_{t-1} \\ \Delta B P_{t-1} \\ \Delta H H I_{t-1} \\ \Delta R E E R_{t-1} \\ \Delta U N E M P_{t-1}\end{array}\right]+\left[\begin{array}{l}\gamma_{0} \\ \gamma_{9}\end{array}\right]^{\prime}\left[\begin{array}{l}1 \\ t\end{array}\right]+\varepsilon_{0}$

The $\alpha$ coefficient represents the restoring force on long-term equilibrium, which should be significantly negative, in order to validate the VECM estimations. As a result, each imbalance phenomenon tends to fade over time towards a stable equilibrium.

\section{RESULTS AND DISCUSSION}

For the Moroccan economy case, the model estimation shows the overall significance of long-term relationships between the selected variables. However, the short-term estimation of the interdependencies between variables does not give satisfactory results. Using Python 3.8 software, the short-term estimated parameters will be reported in the equation below.
Table 1. Short-Term Model Estimation.

\begin{tabular}{|c|c|c|c|c|c|}
\hline$\Delta \log (G D P c)_{t}$ & Coef. & Std Error & $\mathbf{z}$ & $\begin{array}{c}P- \\
\text { value }\end{array}$ & \\
\hline ec1 & -0.5914 & 0.214 & -2.77 & 0.006 & $* * *$ \\
\hline$\Delta \log (G D P c)_{t-1}$ & 0.2389 & 0.239 & 1.000 & 0.318 & \\
\hline$\Delta \log (D V A)_{t-1}$ & 0.5227 & 0.233 & 2.247 & 0.025 & $* *$ \\
\hline$\Delta \log (F V A)_{t-1}$ & -0.4332 & 0.183 & -2.364 & 0.018 & $* *$ \\
\hline$\Delta \log (E X P)_{t-1}$ & 0.4525 & 0.348 & 1.301 & 0.193 & \\
\hline$\Delta B P_{t-1}$ & -0.0012 & 0.007 & -0.177 & 0.860 & \\
\hline$\Delta H H I_{t-1}$ & -0.0021 & 0.003 & -0.855 & 0.393 & \\
\hline$\Delta \operatorname{REEP}_{t-1}$ & -0.0032 & 0.007 & -0.473 & 0.636 & \\
\hline$\Delta U N E M P P_{t-1}$ & -0.0215 & 0.026 & -0.831 & 0.406 & \\
\hline TREND & 0.0082 & 0.003 & 2.836 & 0.005 & **** \\
\hline
\end{tabular}

Based on these results, we note firstly that only the variables corresponding to integration into global value chains are statistically significant at 5\% risk. In other words, economic growth in Morocco and per capita income are significantly impacted by the national economy integration in GVCs. As a result, the DVA variable coefficient, which represents the Domestic Value Added incorporated into national exports, positively impacts economic growth in the long-term. contrariwise, increasing foreign added value in Moroccan exports, represented by the FVA variable, penalizes growth of GDP per capita over time. Although the other variables have a close relationship with economic growth according to the literature review, their impact is limited in the short term for the case of the Moroccan economy.

Secondly, the negative sign of the $\alpha$ coefficient as well as its high significance at $1 \%$ risk means restoring the GDP per capita balance even if it suffers a shock from the chosen variables, particularly from those linked to participation in global value chains. Besides, about $59 \%$ of the losses caused by negative shocks will be recovered after just one year in order to return to equilibrium.

Then, the estimation of long-term relationships gives very significant coefficients compared to Wald's statistics. The estimated parameters have consistent signs with what is theoretically described. This underlines the importance of the selected variables in estimating the impact of integration into the GVC's. Of this observation, this model may prove useful in the case of countries that have a productive structure close to that of Morocco. The results of this estimation are represented in the following table:

Table 2. Estimated Long-Term Relationships.

\begin{tabular}{|c|c|c|c|c|c|}
\hline $\log (\boldsymbol{G D P c})_{t-1}$ & Coef. & $\begin{array}{c}\text { Std } \\
\text { Error }\end{array}$ & $\mathbf{z}$ & $\begin{array}{c}\text { P- } \\
\text { value }\end{array}$ & \\
\hline $\log (\boldsymbol{D V A})_{t-1}$ & -0.354 & 0.042 & -8.460 & 0.000 & $* * *$ \\
\hline $\log (\boldsymbol{F V A})_{t-1}$ & 0.474 & 0.030 & 15.882 & 0.000 & $* * *$ \\
\hline $\log (\boldsymbol{E X P})_{t-1}$ & -0.457 & 0.026 & -17.556 & 0.000 & $* * *$ \\
\hline
\end{tabular}


Fig. (3). Evolution of Exports and domestic added value in Exports, Morocco 1990-2018.

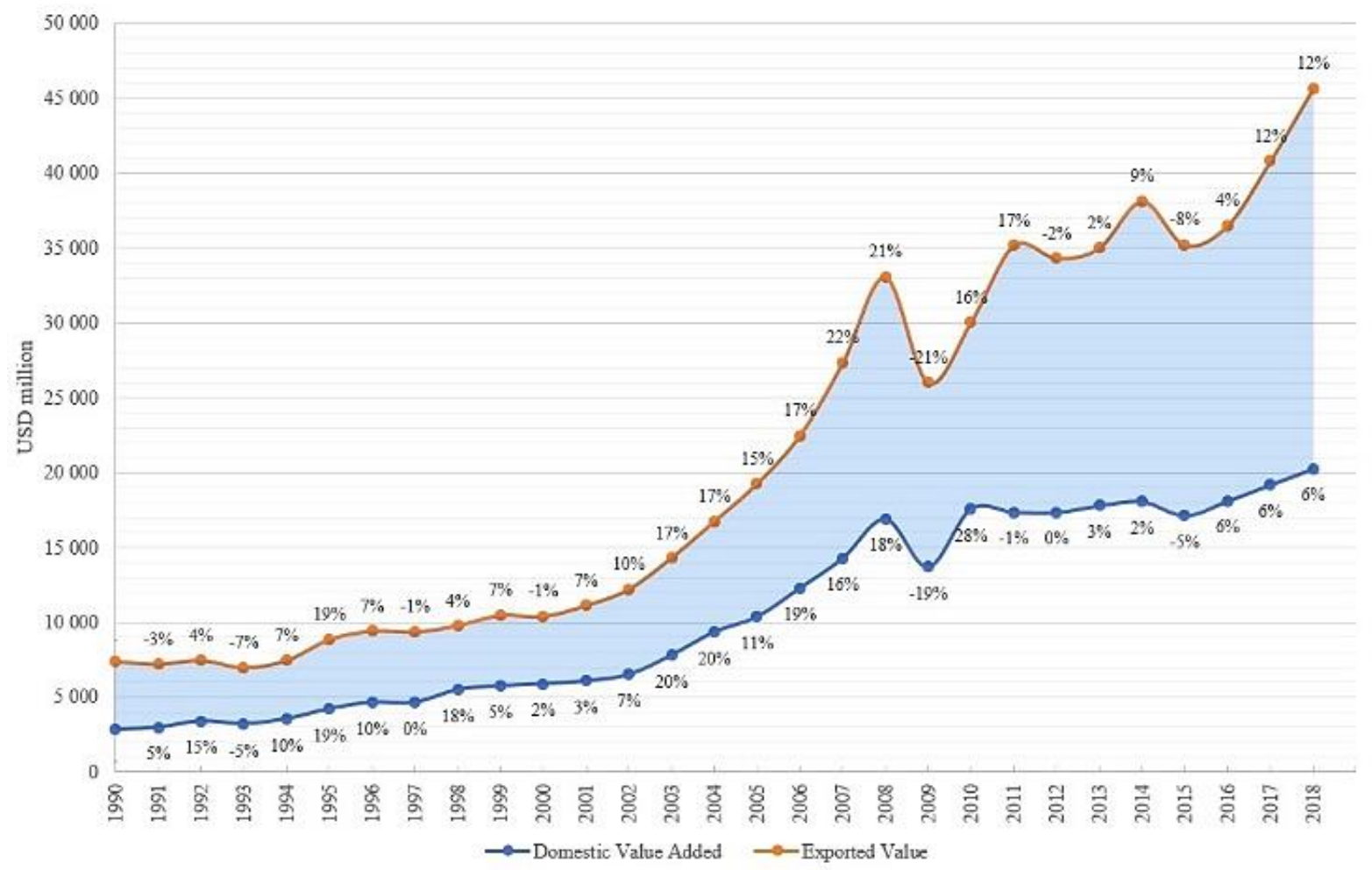

Source: Elaborated by the authors on the basis of World Bank data and the TiVA database.

\begin{tabular}{|c|c|c|c|c|c|}
\hline $\boldsymbol{B P}_{t-1}$ & 0.030 & 0.001 & 31.104 & 0.000 & $* * *$ \\
\hline $\boldsymbol{H H I}_{t-1}$ & 0.005 & 0.001 & 4.879 & 0.000 & $* * *$ \\
\hline $\boldsymbol{R E E P}_{t-1}$ & 0.006 & 0.001 & 4.798 & 0.000 & $* * *$ \\
\hline $\boldsymbol{U N E M P}_{t-1}$ & 0.070 & 0.004 & 15.987 & 0.000 & $* * *$ \\
\hline
\end{tabular}

long-term economic growth and subsequently increase the per capita income. For this reason, public authorities in Morocco need to develop strategies for upgrading GVCs and to move towards a new production model based on export sophistication.

We also note that exports contribute significantly to wealth creation. For Morocco, a $1 \%$ increase in exports leads to a $0.45 \%$ increase in GDP per capita. But this effect is also less than the negative impact of the foreign value added (FVA). This result explains partly the root causes of the limited participation of foreign trade in economic growth.

Despite the efforts made to better boost the industrial sector in Morocco, it remains a sector with low contribution of added value compared to all sectors, where the lack of a real structural transformation is to blame. Thus, notwithstanding the higher integration of Morocco in GVCs over the past ten years, the national value added included in those exports has evolved rather slowly, even with strong development of exports in value (see Fig. 3) ${ }^{3}$. We note that exports in value increased by $52 \%$ between 2010 and 2018, while the domestic value added included in these exports increased only by $15 \%$ during the same period. This means that Morocco's integration into global value chains at some stage (usually assembly activities) does not lead to significant creation of added value. This situation is the main cause of the Moroccan foreign trade weakness and its inability to participate in economic development. Consequently, the leading firms are of increased domestic value added within the GVCs system. This means that the actual form of Morocco's integration in GVCs does not benefit economic growth in the long-term. In other words, Morocco's position within the global production chains does not generate enough added value to boost

\footnotetext{
${ }^{3}$ The shown percentages represent the annual growth rate.
} 
Fig. (4). Prospect for market diversification for a product exported by Morocco in 2019.

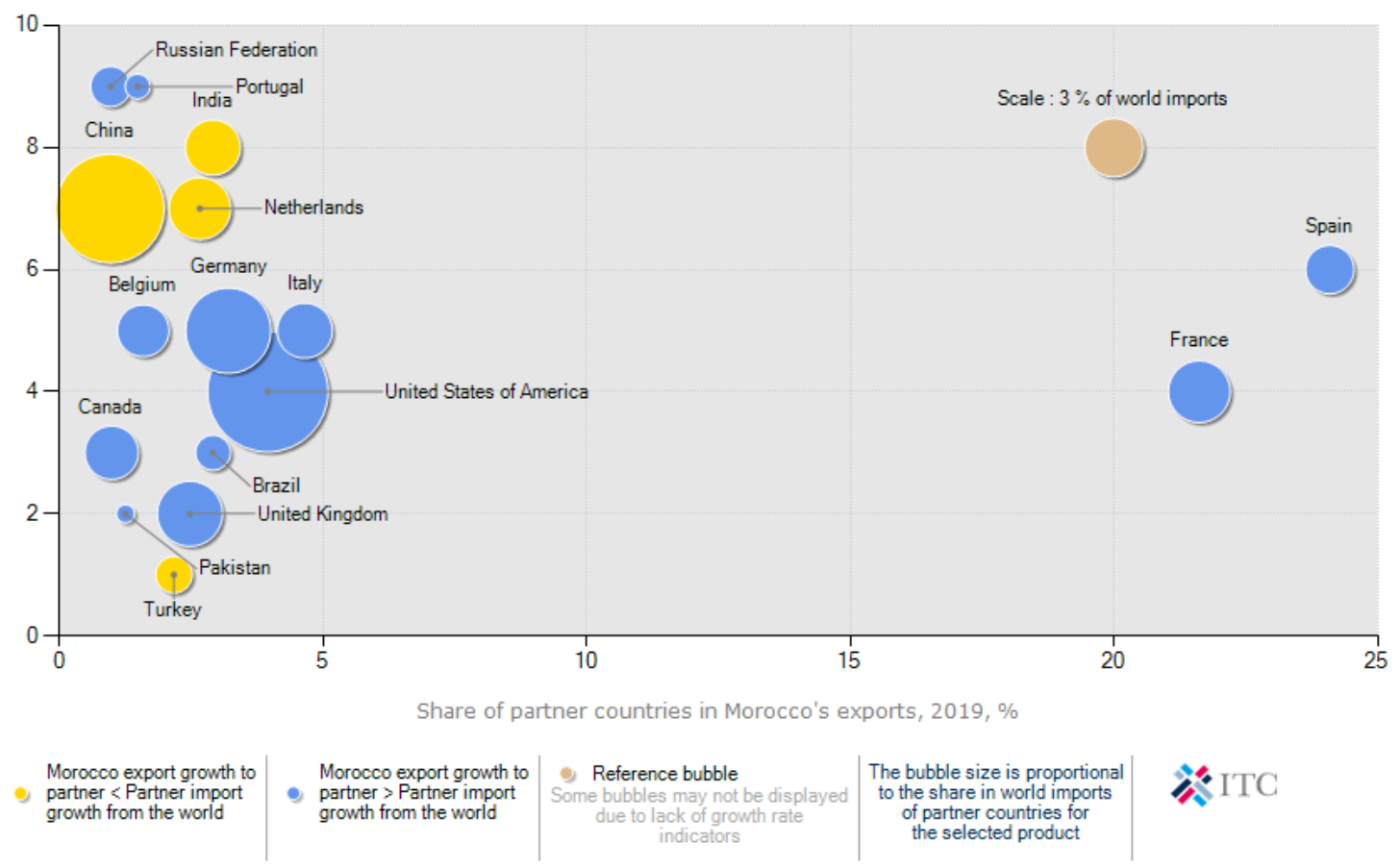

Source: Trade competitiveness map. URL: https://cutt.ly/OyVAR23.

considered the biggest beneficiaries of the increase in goods re-exported under GVCs.

It should be noted that the high concentration of these exports on the European market, especially France and Spain, makes Morocco very vulnerable to changes in the economic situation of the European Union. The limited geographical diversification of exports prevents the national economy from taking advantage of other rapidly expanding markets such as Brazil, India and China, where long-term growth prospects seem favorable (Agénor and El Aynaoui, 2015). In addition to the Netherlands and Turkey, the Chart below shows that Moroccan exports are evolving slowly compared to import demand in these countries in 2019. This means that Morocco is not taking enough advantage from the expansion of these emerging markets and from the growing demand in these countries. In this situation, Morocco loses real opportunities to develop its foreign trade. So, Morocco's trade policy concentration on production instead of promotion and prospecting for new markets is one of the main limitations of Moroccan foreign trade.

As for employment, the results of our estimates approve what was previously cited in the literature review. For the case of Morocco, integration into GVCs has no significant impact on total employment. Its coefficient is not statistically significant as shown in appendix 2. Furthermore, the unemployment rate in Morocco didn't show a noticeable decline since 2010. Although the unemployment rate has stayed almost constant at around $9 \%$ since 2010, the decrease in the unemployment rate recorded for employees with an average degree or even those without a degree, has been counterbalanced by a rise in unemployment for those with advanced degrees (see appendix 3). Therefore, we conclude that the level of employment in Morocco is more decided by other economic variables than its current integration form in the GVCs. We therefore conclude that employment increased only in countries where participation in GVCs raised significantly local value added in exports(African Development Bank and al., 2014).

\section{CONCLUSION}

The results of econometric modeling show that the integration of Morocco into GVCs does not effectively participate in improving the country's economic performance. the negative effect on economic growth induced by foreign value added exceeds the positive impact of increased domestic value added within the GVCs system. Thus, notwithstanding the higher integration of Morocco in GVCs over the past ten years, the national value added included in those exports has evolved rather slowly, even with strong development of exports in value. As a result, Morocco's current stage in GVCs does not allow an increase of per capita income and an improvement of employment rates. It should also be noted that the high concentration of Moroccan exports in a limited number of countries weakens the ability to profit enough from the expansion of other emerging markets to take full advantage of opportunities offered by world trade.

However, integration into a GVC is accompanied by access to new production networks, capital, know-how and technologies. This participation in the global production process is often considered as the first step on development path. In this regard, the main objective of this paper is to recommend developing a strategy to move upmarket in the GVCs, and to raise awareness of the importance of a new production model based on the exports' sophistication. 


\section{APPENDICES}

\section{APPENDIX 1}

Fig. (5). Evolution of the studied variables, Morocco 1990-2018.
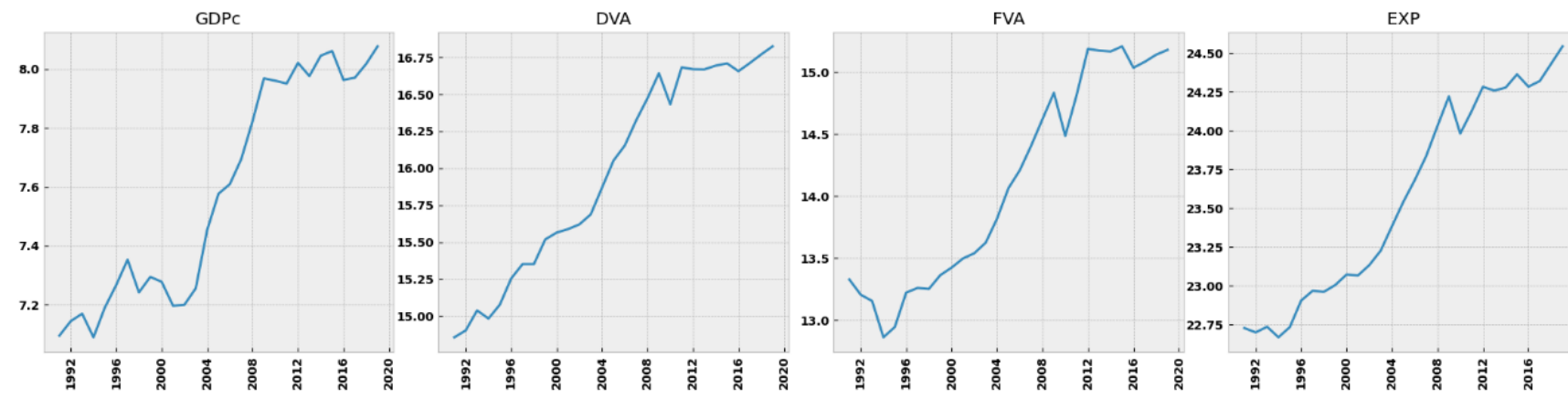

BP

$\mathrm{HHI}$
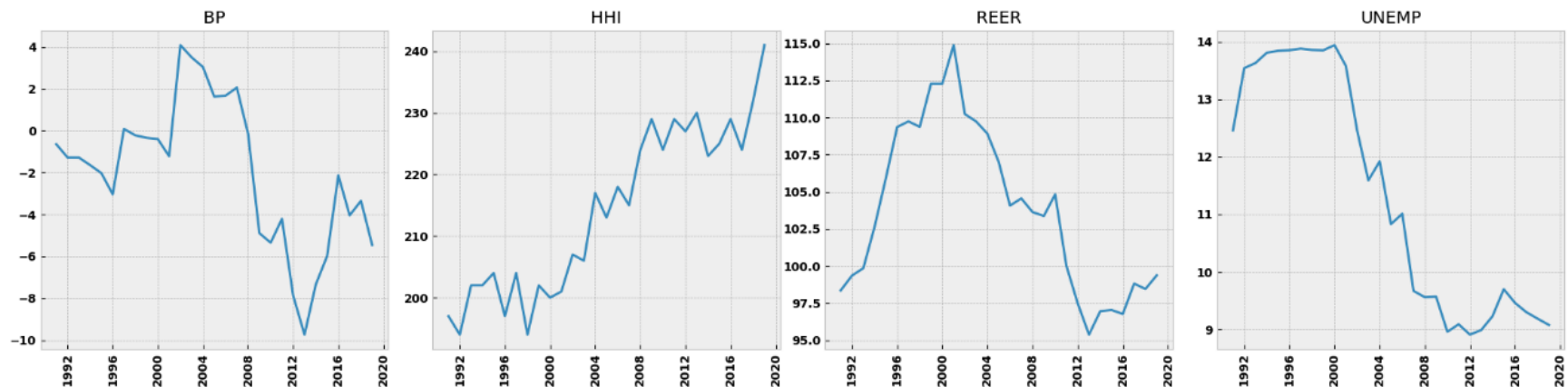

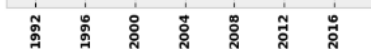

APPENDIX 2

Table 3 - Estimation of the impact of integration in GVCs on unemployment in Morocco, 1990-2018

\begin{tabular}{|c|c|c|c|c|}
\hline ec1 & -1.363 & 1.422 & -0.958 & 0.338 \\
\hline$\Delta \log (G D P c)_{t-1}$ & 2.3137 & 1.591 & 1.454 & 0.146 \\
\hline$\Delta \log (D V A)_{t-1}$ & 1.2453 & 1.549 & 0.804 & 0.421 \\
\hline$\Delta \log (E X P)_{t-1}$ & -2.0331 & 2.316 & -0.878 & 0.380 \\
\hline$\Delta B P_{t-1}$ & 0.0059 & 0.047 & 0.126 & 0.900 \\
\hline$\Delta H_{H} I_{t-1}$ & -0.0328 & 0.017 & -1.960 & 0.050 \\
\hline TREND & 0.0140 & 0.019 & 0.732 & 0.464 \\
\hline
\end{tabular}




\section{APPENDIX 3}

Fig. (6). Evolution of the unemployment rate, Morocco 1999-2018.

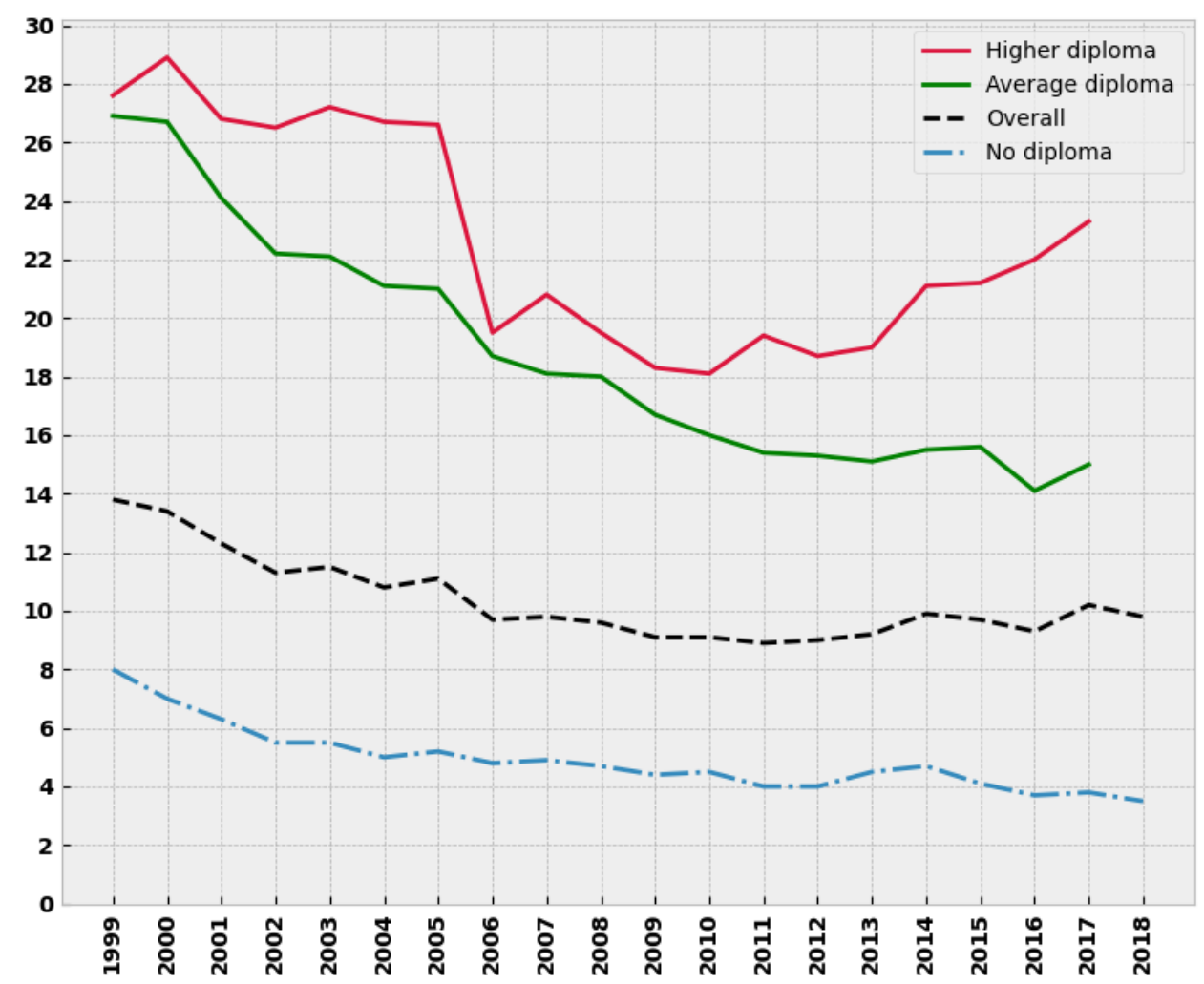

Source : HCP, Morocco.

\section{APPENDIX 4}

Fig. (7). Correlation of the studied variables pairwise based on Domestic Value Added, Morocco.

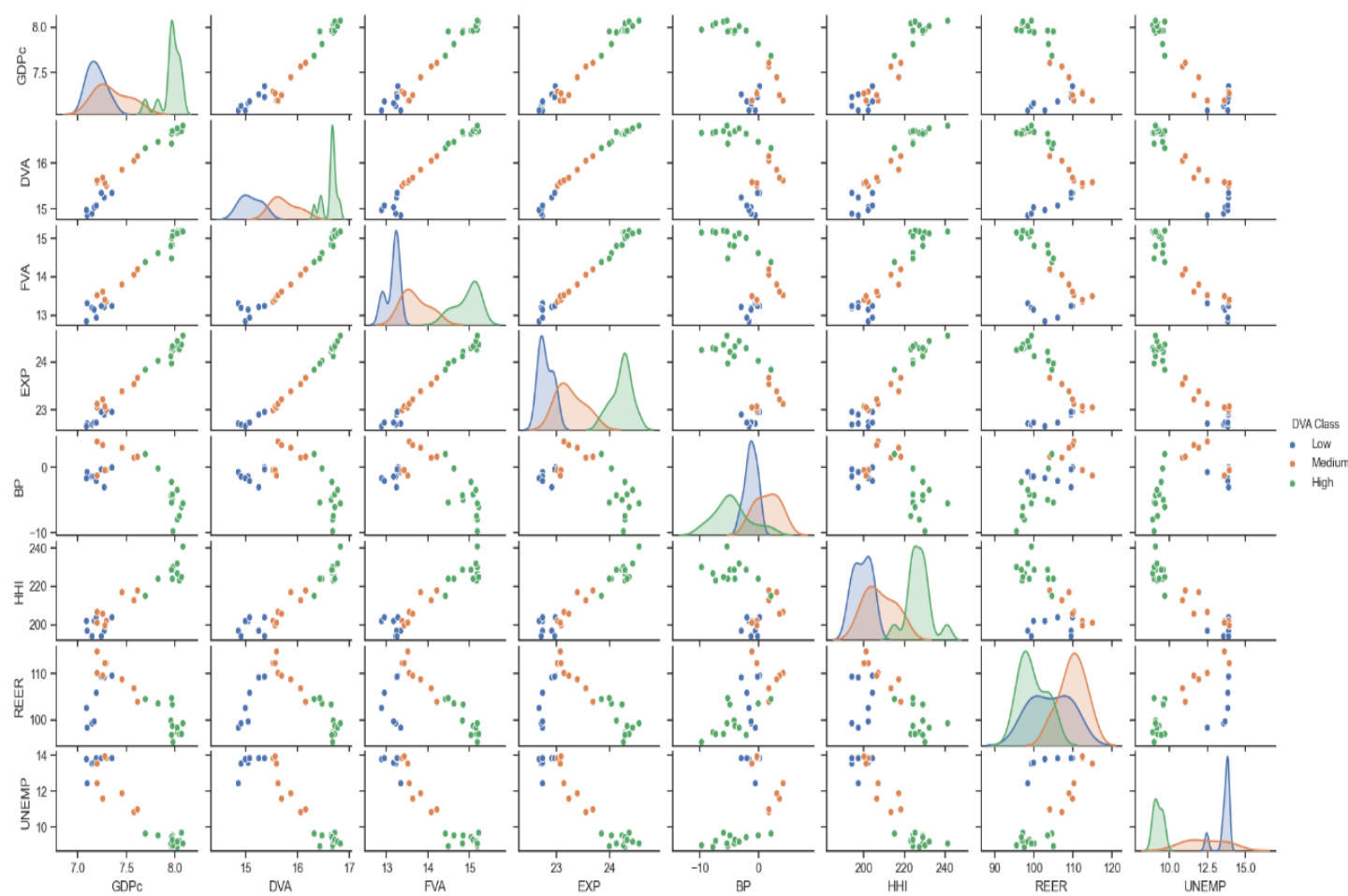




\section{CONFLICT OF INTEREST STATEMENT}

The authors declare that they have no conflict of interest.

\section{REFERENCES}

African Development Bank, OECD, UNDP, 2014. Perspectives économiques en Afrique 2014: Les chaînes de valeur mondiales et l'industrialisation de l'Afrique, Perspectives économiques en Afrique. OECD. https://doi.org/10.1787/aeo-2014-fr

Agénor, P.-R., El Aynaoui, K., 2015. Politiques publiques, transformation industrielle, croissance et emploi au Maroc: une analyse quantitative. Revue d'économie du développement 23, 31-69.

Arnold, J.M., Javorcik, B., Lipscomb, M., Mattoo, A., 2016. Services Reform and Manufacturing Performance: Evidence from India 59.

Augier, P., CASTEL, V., EL MALKI, T., 2019. Rapport FEMISE EuroMed 2019: Identification des obstacles à l'intégration dans les chaînes de valeur mondiales des PME marocaines.

Brulhart, F., Favoreu, C., Gherra, S., 2015. Stratégie. Dunod.

Fallis, A.G., 2013. A Portrait of Global Patterns and Several Testable Hypotheses. Journal of Chemical Information and Modeling 53, 16891699. https://doi.org/10.1017/CBO9781107415324.004

Forum, W.E., 2013. Enabling trade valuing growth opportunities. World Economic Forum Geneva, Switzerland.

Gereffi, G., Lee, J., 2012. Why the World Suddenly Cares About Global Supply Chains. J Supply Chain Manag 48, 24-32. https://doi.org/10.1111/j.1745-493X.2012.03271.x

Hummels, D., Ishii, J., Yi, K.-M., 2001. The nature and growth of vertical specialization in world trade. Journal of international Economics $54,75-96$.

Jaidi, L., Msadfa, Y., 2017. La Complexité de la Remontée des Chaînes de valeur Mondiale: Cas des Industries Automobile et Aéronautique au Maroc et en Tunisie/The Complexity of the Rise of Global Value Chains: The Case of Automotive and Aeronautics Industries in Morocco and Tunisia.
Kummritz, V., 2016. Do global value chains cause industrial development? The Graduate Institute of International and Development Studies, Centre for Trade and Economic Integration.

Lotfi, B., Karim, M., 2017. Export Diversification and Economic Growth in Morocco: An Econometric Analysis. Applied Economics and Finance 4, 27-35.https://doi.org/10.11114/aef.v4i6.2673

Lotfi, B., Karim, M., 2016a. Competitiveness Determinants of Moroccan Exports: Quantity-Based Analysis. IJEF 8, 140 https://doi.org/10.5539/ijef.v8n7p140

Lotfi, B., Karim, M., 2016b. Dutch Disease and Changes of the Productive Structure in Moroccan Economy. An Analysis Using VECM. Advances in Management and Applied Economics 6, 25.https://cutt.ly/ayBgPAr

Montalbano, P., Nenci, S., Pietrobelli, C., 2018. Opening and linking up: firms, GVCs, and productivity in Latin America. Small Bus Econ 50, 917-935. https://doi.org/10.1007/s11187-017-9902-6

OECD, 2014. Économies interconnectées: Comment tirer parti des chaînes de valeur mondiales. OECD. https://doi.org/10.1787/9789264201842-fr

OECD, 2013. Perspectives on Global Development 2013.

OECD, WTO, 2014. Panorama de l'aide pour le commerce 2013: Se connecter aux chaînes de valeur, Panorama de l'aide pour le commerce. OECD. https://doi.org/10.1787/aid_glance-2013-fr

OMC | Nouvelles 2017 - Des chaînes de valeur mondiales plus inclusives peuvent favoriser la productivité et la croissance dans les pays en développement [WWW Document].URL https://www.wto.org/french/news_f/news17_f/igo_10jul17_f.htm (accessed 6.4.20).

Raei, F., Ignatenko, A., Mircheva, B., 2019. Global Value Chains: What are the Benefits and Why Do Countries Participate? IMF Working Papers 19, 1. https://doi.org/10.5089/9781484392928.001

World Bank, 2019. World Development Report 2020: Trading for Development in the Age of Global Value Chains. The World Bank. https://doi.org/10.1596/978-1-4648-1457-0 